

Journal Website: http://usajournalshub.c om/index,php/tajpslc

Copyright: Original content from this work may be used under the terms of the creative commons attributes 4.0 licence.

\section{The Methods Of The Imposition Of A More Lenient Punishment According To The Legislation Of The Republic Of Uzbekistan}

Mukhayyo Karamatullo Qizi Akbaralieva

Masters Student, Tashkent State University Of Law, 5A240116 «Theory And Practice Of The Application Of Criminal Legislation», Uzbekistan

\title{
ABSTRACT
}

All the ways of the imposition a more lenient punishment are considered particularly in the article. The issues of individualization of punishment are also discussed. The article deals with the general principles of sentencing. The article examines the aspects of the application of each method of the imposition a more lenient punishment, under what circumstances each method is used, and under what circumstances it is impossible to apply a concrete method. Examples from the legislation of the Republic of Uzbekistan are also given. The article analyzes the sanctions of the articles of the Special Part of the Criminal Code of the Republic of Uzbekistan. The article considers the authors' opinions on certain issues.

\section{KEYWORDS}

The imposition a more lenient punishment, individualization of punishment, general principles of sentencing, the methods of the imposition of a more lenient punishment, punishment below the lower limit, system of penalties, sanction.

\section{INTRODUCTION}

Sentencing is the activity of a court aimed at applying measures of state influence to a 
person found guilty of a crime, which is expressed in the choice of the type and amount of punishment.

The penalty is imposed on the basis of the general principles provided for in article 54 of the Criminal Code of the Republic of Uzbekistan.

According to this norm, the penalty is established within the scope of the article's sanction based on the provisions of the General Part of the Criminal Code. The following circumstances are taken into account in the general principles of sentencing: 1) the nature and degree of public danger; 2) the motive; 3 ) the nature and extent of the harm caused; 4) the identity of the perpetrator; 5) the circumstances mitigating and aggravating the punishment.

\section{THE MAIN RESULTS AND FINDINGS}

These rules apply to every criminal case, which is why they are called general rules. But at the same time, there are special rules for sentencing.

The penalty, according to the criminal legislation of the Republic of Uzbekistan, is applied for the purposes of: 1) correcting a person; 2) preventing the continuation of criminal activity; 3) preventing the commission of new crimes by both convicted persons and other persons.

The issues of individualization of punishment are currently the most relevant when assigning punishment.

Individualization of punishment is expressed in the maximum compliance of criminal-legal measures of influence to the goals of punishment, taking into account the degree of public danger of the crime committed by the person and data about his personality, including mitigating and aggravating circumstances.

The imposition of a more lenient sentence is a special rule of sentencing. Special rules help to individualize the punishment as much as possible. When assigning a more lenient sentence, one of the main tasks of sentencing is carried out - the humanization of punishment.

According to article 57 of the Criminal Code of the Republic of Uzbekistan, there are three ways to impose a more lenient sentence.

The first method is the imposition of a penalty below the lowest limit provided for in the article of the Special Part of the Criminal Code for this crime.

When imposing a sentence below the lowest limit, the court chooses the type of punishment specified in the sanction of the article, but at the same time reduces the minimum term or the amount of this punishment.

For the application of this method, the minimum term or the amount of punishment must be specified in the sanction of the article.

For the application of this method, the minimum term or the amount of punishment must be specified in the sanction of the article. If the lower limit is not specified, the court cannot apply this method. The Criminal Code of the Republic of Uzbekistan contains a sufficient number of articles, the sanctions of which do not specify the minimum term or the amount of punishment. For example, part 1 of Article 111 of the Criminal Code of the Republic of Uzbekistan (Negligent infliction of moderate bodily injury is punishable by a fine of up to twenty-five basic calculation values or 
mandatory community service of up to three hundred hours or correctional labor of up to two years); part 1 of Article 167 (Theft by misappropriation or embezzlement of other people's property entrusted to the guilty person or under his jurisdiction, is punishable by a fine of up to one hundred basic calculation values or mandatory community service of up to two hundred and forty hours or correctional labor of up to one year); part 1 of Article 221 of the Criminal Code of the Republic of Uzbekistan (Disobedience to the legal requirements of the administration of the penitentiary institution is punishable by up to three years 'imprisonment); part 1 of Article 222 of the Criminal Code of the Republic of Uzbekistan (Escape from custody or from custody is punishable by up to five years' imprisonment);

When using this method, some contradictions arise. There is an opinion that underestimating the term of imprisonment below the lowest limit, and not applying instead other more lenient types of punishment specified in the sanction, is inappropriate.

T. V. Nikolaeva on this occasion states the following: «The imposition of the most severe type of punishment in the presence of alternative milder types of punishment in the sanction does not correspond to the idea of mandatory mitigation of punishment in the presence of exceptional mitigating circumstances, since the court could have chosen any type of punishment from among the sanctions provided for, up to the mildest» $[1$, P. 140].

However, E. V. Blagov, in contrast to the above, believes that: "The legislator considered it possible to impose punishment in this way, provided that a less severe type of punishment will not be able to achieve its goals, and the minimum amount of a more severe punishment in this case is high» [2, P. 55].

We agree with the latter opinion. According to article 42 of the Criminal Code of the Republic of Uzbekistan, punishment is applied for the purpose of correcting, preventing the continuation of criminal activity, as well as preventing the commission of new crimes by both convicted persons and other persons. And therefore, the court, based on the above rules, may consider it appropriate to impose a sentence of imprisonment with a reduction in the lower limit, although the sanctions of the article may include other milder types of punishment. For example, the sanction of part 1 of article 104 of the Criminal Code of the Republic of Uzbekistan provides for penalties in the form of restriction of liberty and deprivation of liberty. In a particular case, the court may conclude that a sentence of imprisonment should be imposed to correct the person. And the minimum term of imprisonment, in this case -3 years, can be high. And in this case, the court reduces the minimum term of imprisonment below the lowest limit.

The court, based on the purposes of the punishment, may consider it appropriate to impose a sentence of imprisonment with a reduction of the lower limit, although other milder types of punishment may be included in the sanction of the article.

The second method is the appointment of another, more lenient punishment, which is not provided for in the article of the Special Part of the Criminal Code for this crime.

Article 43 of the Criminal Code reflects the system of punishments. The types of 
punishments are arranged in sequence from less severe to more severe. According to this system, a fine is the mildest form of punishment. And therefore, many believe that if the sanction of a particular article already has this type of punishment, then the use of the second method of assigning a more lenient punishment is impractical.

This opinion is supported by M. N. Stanovsky: «If, for example, the sanction of the article as a punishment provides only for deprivation of liberty for a certain period, then the court has the right to impose any punishment on a person before deprivation of liberty. If, for example, the sanction of the article provides for a penalty in the form of a fine in addition to imprisonment, then the considered option of assigning a milder penalty cannot be applied, since the fine is the mildest type in the system of punishments» [3, P. 283].

In the Criminal Code of the Republic of Uzbekistan, there are also such articles in the sanctions of which the punishments are not in sequence, that is, there is an interval between the punishments. For example, article 237 of the Criminal Code of the Republic of Uzbekistan "False denunciation". The sanction of part 1 of this article provides for penalties in the form of a fine, restriction of liberty and imprisonment. In this case, the question arises: "Can the court in this case apply the second method of assigning a milder penalty, because here, in the sanction of the article, there is already the mildest penalty-a fine". For many convicts, the fine may seem more severe than other types of punishment.

It is not necessary that the type of punishment is milder than the mildest punishment specified in the sanction of the article. It is enough that it is milder than any punishment specified in the sanction.

The third method is the non-application of mandatory additional punishment, the application of which is provided for in the article of the Special Part of the Criminal Code.

When using this method, there are no questions, unlike the two previous methods. This method is applied only if the additional type of punishment in the sanction of the article is established as mandatory, when its application is mandatory together with the other main type of punishment.

In the system of punishments of the Criminal Code of the Republic of Uzbekistan, only the deprivation of a certain right can be both basic and additional. Therefore, the third method of assigning a more lenient punishment is associated with the deprivation of a certain right.

And so, in thirty-two articles of the Criminal Code of the Republic of Uzbekistan, the deprivation of a certain right is established as a mandatory additional punishment. These are the following articles: part 3 of Article 168; Article 175; Article 188; parts 2 and 3 of Article 1921; parts 2 and 3 of Article 1922; parts 2 and 3 of Article 1923; Article 1925; part 2 of Article 1926; part 2 of Article 194; part 2 of Article 195; part 2 of Article 196; part 2 of Article 201; part 2 of Article 205; part 2 of Article 206; part 3 of Article 207; part 2 of Article 209; part 1 of Article 210; article 2294; parts 2,3,4 of Article 2295; article 2301; article 2302; article 235; part 2 of Article 236; article 2411; part 2 of Article 253; part 2 of Article 255; part 2 of Article 257; part 2 of Article 258; Part 2 of Article 259; article 261; parts 2 and 3 of Article 266; part 1 of article 2785. 


\section{CONCLUSION}

Thus, in conclusion, it is worth noting that each method of assigning a milder sentence differs from the others in its rules, originality, and that the court can apply a specific method, it must take into account many circumstances. The imposition of a more lenient sentence is a right of the court, not an obligation. Therefore, the court may apply article 57 of the Criminal Code only if it deems it necessary. It should be noted once again, that when assigning a more lenient sentence, one of the main tasks of sentencing is carried out - the humanization of punishment.

\section{REFERENCES}

1. Николаева Т. В. Назначение более мягкого наказания, чем предусмотрено за данное преступление (вопросы теории и практики). Диссертация на соискание ученой степени кандидата юридических наук. Уфа, 2005. - 190 с. URL: https://www.dissercat.com/content/na znachenie-bolee-myagkogonakazaniya-chem-predusmotreno-zadannoe-prestuplenie-voprosyteor/read.

2. Благов Е. В. Назначение наказания: (теория и практика). - Ярославль: Яросл. гос. ун-т., 2002. - 187 с. URL: http://www.lib.uniyar.ac.ru/edocs/iuni/ 20020906.pdf.

3. Становский М.Н. Назначение наказания. - Санкт Петербург: «Юридический центр Пресс», 1999. $480 \mathrm{c}$. 